\begin{tabular}{|l|l|l||}
\hline \multicolumn{2}{|c|}{ PublisherInfo } \\
\hline \hline PublisherName & $:$ & BioMed Central \\
\hline \hline PublisherLocation & $:$ & London \\
\hline \hline PublisherImprintName & $:$ & BioMed Central \\
\hline \hline
\end{tabular}

\title{
Autoimmunity in BAFF transgenic mice
}

\begin{tabular}{|l|l|l||}
\hline \multicolumn{2}{|c|}{ ArticleInfo } \\
\hline \hline ArticleID & $:$ & 196 \\
\hline \hline ArticleDOI & $:$ & $10.1186 /$ ar-2000-66795 \\
\hline \hline ArticleCitationID & $:$ & 66795 \\
\hline \hline ArticleSequenceNumber & $:$ & 153 \\
\hline \hline ArticleCategory & $:$ & Paper Report \\
\hline \hline ArticleFirstPage & $:$ & 1 \\
\hline \hline ArticleLastPage & $:$ & 4 \\
\hline \hline & & RegistrationDate : 2000-3-24 \\
\hline ArticleHistory & $:$ & OnlineDate \\
\hline ArticleCopyright & $:$ & Current Science Ltd2000-3-24 \\
\hline \hline ArticleGrants & $:$ & \\
\hline \hline ArticleContext & $:$ & 130753311 \\
\hline \hline
\end{tabular}


Chaim Putterman, Aff1

Aff1 Albert Einstein College of Medicine, Ney York, USA

\section{Keywords}

Autoimmunity, BAFF (B cell activating factor), transgenic mice, TNF

\section{Context}

Apoptosis of autoreactive T cells and B cells is an important mechanism by which self-tolerance is normally maintained. A striking example of this is the Fas/Fas ligand pathway, as the presence of defective Fas or Fas ligand molecules leads to lupus-like systemic autoimmunity in the mouse. The authors of this paper have recently identified another TNF-like ligand, which they called BAFF. This molecule has also been independently discovered by other groups and named TALL-1, THANK, and BlyS. BAFF has been shown to be expressed by dendritic cells, and binds to B cells. To further characterize and understand the physiological role of BAFF by generating mice transgenic for BAFF.

\section{Significant findings}

Mackay et al found an expanded B lymphocyte population in spleens and lymph nodes of BAFFtransgenic mice. B cells were also in a state of activation, as shown by increased expression of MHC class II. $b c l 2$ expression was also upregulated. In the T cell compartment, about $50 \%$ of cells expressed

the activated $\mathrm{CD} 44^{\mathrm{hi}}$, L-selectin ${ }^{\mathrm{lo}}$ phenotype. Mature B cell numbers were increased in lymph nodes and spleen, while no change in mature or immature B cells was observed in the bone marrow, suggesting that it is mostly the peripheral mature B cells that are being affected. Histological and immunohistochemical studies confirmed the FACS findings.

BAFF-transgenic mice had significantly higher IgG and IgM levels. Most of the mice were positive for rheumatoid factor in the serum, mainly of the $\operatorname{IgM}, \operatorname{IgA}$, and $\operatorname{IgG} 2$ a isotypes. Increased levels of circulating immune complexes and antibodies to single stranded DNA were also found in about $25 \%$ of the 21 animals examined. Anti-double-stranded-DNA activity was present in three of five mice in which this specificity was looked for. Kidney immunoglobulin deposition was present in six of six mice, and proteinuria $(>+3)$ was found in nine of ten transgenic mice. 


\section{Comments}

This paper by Mackay et al demonstrates that yet another molecule belonging to the tumor necrosis factor (TNF) family may play an important role in autoimmunity. B cell activating factor (BAFF) overexpression in the liver led to a significant expansion of the B cell compartment, although it is unclear if the reason is BAFF-induced proliferation, increased peripheral survival, or a combination of both. As both proliferative effects and upregulation of bcl-2 were seen, the underlying mechanism for the observed B cell expansion remains to be determined. Autoantibodies, renal immunoglobulin deposition, and proteinuria were observed in the transgenic mice. However, this was sometimes only looked for in small groups of varying numbers of animals. Changes in T cells and dendritic cells were also seen, but these were less well characterized. Therefore, while the authors present critical evidence for the role of BAFF in immune regulation, further studies are still necessary to fully understand its precise molecular role. A method to assay circulating BAFF levels would be helpful in this regard, and would also serve to confirm the authors' assumption that BAFF acts as a soluble mediator. Analysis of additional BAFF-transgenic models, with the transgene under control of a different promoter (for example B and/or T cell), might prove interesting. Self-tolerance probably failed in these transgenic mice because of a combination of the effects of BAFF; the critical effect of this interesting molecule remains to be determined. TNF inhibition already plays an important role in the management of treatment-resistant patients with severe rheumatoid arthritis. Elucidating the role of BAFF, another TNF family member, in the etiology of autoimmunity may suggest new therapeutic targets for intervention in autoimmune disease.

\section{Methods}

Transgenic mice overexpressing BAFF were generated under the control of the liver-specific promoter a-1 antitrypsin. Full-length BAFF was expressed with this promoter in order to study the systemic effects if BAFF were cleaved, or local liver changes if the molecule remains membrane-bound. Overexpression of BAFF was confirmed by northern blot. While an ELISA for BAFF was not available, the presence of soluble BAFF in the serum of the transgenic mice was supported by functional assays: serum from BAFF-transgenic mice inhibited the binding of soluble BAFF to BJAB cells, and increased human B cell proliferation with anti-IgM stimulation. B- and T cell compartments were analyzed by fluorescence-activated cell sorter (FACS) analysis. B cell subsets were analyzed in the bone marrow, spleen and mesenteric lymph nodes, to determine if BAFF was acting centrally on B cells, or in the periphery. In addition, histological, immunohistochemical, and serological analyses were carried out to elucidate the phenotype of BAFF overexpression. 


\section{References}

1. Mackay F, Woodcock SA, Lawton P, Ambrose C, Baetscher M, Schneider P, Tschopp J, Browning JL: Mice transgenic for BAFF develop lymphocytic disorders along with autoimmune manifestations. J Exp Med. 2000, 190: 1697-1710.

This PDF file was created after publication. 